\title{
SISTEM REWARD PRODUK PT. NATURAL NUSANTARA CABANG PALU TIMUR DITINJAU DALAM HUKUM ISLAM
}

\author{
Nahwia \\ Program Studi Hukum Ekonomi Syariah IAIN Palu \\ Email: nahwiawosu1996@gmail.com
}

\begin{abstract}
ABSTRAK
Hasil Penelitian menunjukan bahwa pertama Sistem Reward Produk PT. Natural Nusantara yang diberikan kepada Mitra- Nya menggunakan aturan dan penentuan poin dalam pemberian Reward untuk memberi motivasi dan semangat agar MitraNya lebih semangat dalam penjualan dan mengembangkan perusahaan tersebut untuk menjaga kelangsungan perusahaan. Pulis menyarankan agar Para Mitra PT. Natural Nusantara Cab. Palu Timur Kebanyakan Upline memberikan Poin sesuai penjualan Downline. Setiap Upline memberikan semangat dan mengajarkan Downline- Nya agar lebih meninggkat penjualan nya selain itu seorang Upline memberikan saran agar Downline bisa menyetok produk sendiri dan diberikan dengan harga dibawah harga anggota sehinga Downline nya mendapatkan keuntungan yang lebih tinggi. kedua sistem Reward produk PT. Natural Nusantara Cab. Palu Timur adalah sistem Reward apa bila mengutungkan diatas dan perusahaan hanya menjanjikan maka tidak diboleh dalam hukum Islam namun sistem Reward produk PT. Natural Nusantara telah sesuai dengan hukum Islam karena disini Perusahaan telah menyediakan Reward sesuai penjualan Mitra- Nya dan kerja keras seorang Mitra.
\end{abstract}

Kata Kunci : Sistem Reward, Produk, PT. Natural Nusantara, Hukum Islam

\section{A. PENDAHULUAN}

1. Latar Belakang 
Manusia keberadaannya sangat penting dalam perusahaaan, karena sumber daya yang dimiliki oleh manusia dapat menunjang perusahaan yakni dengan melalui karya, bakat, kreativitas, dorongannya dan peran nyata dapat disaksikan dalam setiap perusahaan ataupun dalam organisasi. ${ }^{1}$ Sumber daya manusia dapat mempengaruhi efektifitas dan efisiensi perusahaan, sekaligus merancang alur kegiatan perusahaan, mengawasi kualitasnya dan mengalokasikan sumber daya yang ada serta membentuk tujuan perusahaan.

Sumber daya yang mampu melakukan itu adalah karyawan yang berkualitas dan profesional yang mampu menjalankan aktivitas peusahaan. Untuk meningkatkan

\footnotetext{
${ }^{1}$ Veithzal Rivai Zainal, Islamic Human Capital Manajemen Sumber Daya Insani, (Jakarta : Ed.Revisi 2, Rajawali Pers, 2014), 11.
}

kinerja yang efektif, maka instansi pemerintah atau organisasi dapat memperhatikan hal yang paling utama yakni pemenuhan kebutuhan karyawannya. $^{2} \quad$ Manajemen kompensasi penting untuk meningkatkan motivasi pegawai mencapai prestasi yang yang baik.

Manajemen adalah suatu kegiatan dalam merencang, mengelola, dan mengoperasikan sebuah usaha atau bisnis yang mencakup semua pengaturan baik dari dalam proses pengerjaan, pengelolaan sampai cara mencapai suatu tujuan bisnis yang diinginkan. Reward adalah imbalan yang diberikan oleh perusahaan kepada karyawannya atas jasa atau kontribusinya terhadap perusahaan.

Konpensasi adalah prestasi yang tinggi harus diberi penghargaan (Reward) yang layak dan apabila melanggar aturan dalam organisasi harus diberikan sangsi yang setimpal serta adil. Reward Atau penghargaan

${ }^{2}$ Liesda, Mitra Tertinggi PT. Natural Nusantara Hasil Observasi, Sistem Reward Prodak Nasa di Jl.Tombolotutu, Kec.Mantikulore 16 Juli 2019. 
adalah pengaruh atas orang lain yang didasarkan pada harapan imbalan, lawan dari kekuatan memaksa. Seorang bawahan merasakan bahwa jika memenuhi keinginan seseorang atasan maka ia akan mendapat imbalan positif, baik imbalan keuangan ataupun imbalan psikologi. Reward atau penghargaan pada dasarnya dapat saling menggantikan dengan istilah kompensasi, yang artinya segala bentuk pembayaran atas balas jasa yang diberikan bagi seseorang atas hasil pekerjaanyang dilakukannya. $^{3}$

Tujuan utama perusahaan didirikan, selain untuk memenuhi kebutuhan manusia adalah untuk mendapatkan keuntungan yang layak. Dengan adanya keuntungan yang layak maka dimungkinkan suatu perusahaan dapat mempertahankan kelangsungan hidupnya bahkan dapat

${ }^{3}$ Liesda, Mitra Tertinggi PT. Natural Nusantara, Hasil Observasi, Sistem Reward Prodak Nasa di Jl.Tombolotutu, Kec.Mantikulore 16 April 2019. mengembangkan usahanya untuk lebih maju dan berkembang. ${ }^{4}$ Salah satu cara perusahaan untuk dapat meningkatkan mutu dan kualitasnya ialah dengan cara memberikan reward atau semacam imbalan kepda karyawan dari perusahaan tersebut.

PT. Natural Nusantara, tujuan utama ialah untuk memenuhi kebutuhan karyawanya yang lebih banyak dan mengubah pola pendapatan mereka. untuk itu perusahaan harus selalu berusaha menghasilkan produk yang lebih berkualitas yang harganya begitu tinggi ketika di perjual belikan serta memberikan Reward yang lebih tinggi terhadap karyawan agar dalam melakukan aktifitas pada perusahan lebih baik dan profesional dan dapat meningkatkan kualitas perusahaan tersebut. $^{5}$

Produk PT. Natural Nusantara yang di terapkan berasal dari bahasa MLM adalah berupa penghargaan yang telah diberikan oleh perusahaan kepada upline nya atas kerja keras

\footnotetext{
${ }^{4}$ Hasan Aedy. Teori dan Aplikasi Ekonomi Pembangunan Prespektif Islam, (Yogyakarta Graha Ilmu, 2011). 78

${ }^{5}$ Liesda, Mitra Tertinggi PT. Natural Nusantara Hasil Observasi, Sistem Reward Produk Nasa, di Jl. Tombolotutu, Kec. Mantikulore 16 April 2019
} 
dalam memasarkan produk dan dalam menarik mitra baru untuk bergabung, PT. Natural Nusantara ini bisa juga disebut MLM. ${ }^{6}$

PT. Natural Nusantara, menjadi karyawan sebagian penting dalam kemajuan perusahaan, maka dari itu perusahaan harus memberikan reward bagi karyawan yang mampu bekerja dengan baik. PT. Natural Nusantara juga menyadari bahwa pemberian Reward yang kurang baik akan mendorong seseorang untuk berusaha mencari sumber pendapatan dari sumber lain, hal ini akan sangat merugikan perusahaan karena karyawan membagi konsentrasi kerjanya pada dua hal, yang berakibat menurunnya tingkat produktifitas kerja karyawan dan tidak tercapainnya target perusahaan. ${ }^{7}$ Masalah penghargaan sangat berkaitan erat, antara

${ }^{6}$ Ibid April 2019

Kepala Mitra PT. Natural Nusantara, Buku Pedoman PT. Natural Nusantara, 3 keinginan karyawan dan keinginan perusahaan yang sama-sama ingin dipenuhi, maka perhatian perusahaan kepada karyawan melalui pemberian penghargaan berupa materi maupun non-materi harus dilakukan dengan sebenarnya dan sewajarnya berprestasi untuk keluar dari perusahaan dan mencari kegiatan lain. Hal ini dapat meningkatkan kedisiplinan kerja karyawan dan pada akhirnya akan meningkatkan produktifitas kerja serta pencapaian target perusahaan PT. Natural Nusantara. seseorang karyawan akan berprestasi ketika kinerjanya dihargai, sebaliknya jika usahanya tidak dihargai maka ia tidak akan berupaya untuk berprestasi. ${ }^{8}$

PT. Natural Nusantara ini menentukan poin setiap produk dalam penjualan produk itu dapat poin dan sistem Reward menyediakan penghargaan terhadap distributor dalam meningkatkan pemasaran dan peningkatan menarik

\footnotetext{
${ }^{8}$ Sopyan, Syafri Harahap, Manajemen Kontemporer, Jakarta: Cet. Kesatu, Raja Grafindo Persada, 2005, 200
} 
mitra baru untuk bergabung. agar lebih banyak mitra PT. Natural Nusantara.

\section{Rumusan Masalah}

Dari latar belakang sebagaimana yang telah penulis kemukakan sebelumnya, maka penulis akan merumuskan pokok masalah yang akan dibahas ini yaitu "Sistem Reward Produk PT. Natural Nusantara Cabang Palu Timur Ditinjau Dalam Hukum Islam”.

Adapun sub masalahnya yaitu:

a. Bagaimana Sistem Reward Produk PT. Natural Nusantara Cabang Palu Timur?

b. Apakah Sistem Reward Produk PT. Natural Nusantara Cabang Palu Timur Telah Sesuai Dalam Hukum Islam?

\section{Metodologi Penelitan}

Adapun Jenis penelitian yang akan di gunakan oleh penulis pada Sekeripsi ini ialah jenis penelitian deskritif dengan pendekatan kualitatif. Penelitian deskriptif adalah penelitian yang mengambarkan suatu kajian objeknya yaitu mengenai gejala-gejala, peristiwa-peristiwa serta fenomena yang terjadi pada lingkungan suatu unit sosial baik individu, kelompok, lembaga ataupun mitra $^{9}$ Penelitian ini menggunakan penelitian kualitatif yaitu prosedur penelitiannya menghasilkan data deskriktif dengan melakukan pengamatan pada objek penelitian dan kemudian di lakukan dengan analisis.

Dalam hal ini penyusun memberikan gambaran kepada pembaca tentang keadaan yang terjadi pada objek penelitian yaitu Sistem Reward Produk PT.Natural

${ }^{9}$ Sumadi Suryabrata, Metodologi Penelitian, (Cet.23 Jakarta : PT RajaGrafindo, 2013), 75 
Islam.

\section{B. PEMBAHASAN}

\section{Penelitian Terdahulu}

Permasalahan dalam sistem Reward produk PT. Natural Nusantara bukalah hal yang baru untuk diangkat dalam sebuah skripsi maupun dalam tulisan literatur lainnya. Sebelumnya telah banyak buku-buku atau karya ilmia lainnya yang membahas tentang sistem reward prodak nasa diantaranya :

1. Penelitian yang dilakukan pada tahun 2017 oleh Ibu Ranita Dewi, S.H.I yang berjudul "Tinjauan Hukum Ekonomi Islam Tentang Reward Dan Punishment Karyawan (Studi Pada PT. Plato Isoiki Bandar Lampung).” Dimana penelitian ini membahas tentang Reward di PT. Plato Isoiki Bandar Lampung yang sistem Reward nya tidak sesuai dengan Hukum Islam.
Reward yang ada di PT. Plato Isoiki berupa gaji, bonus, uang lembur dan tunjangan kesehatan. Punishment yang diberikan adalah peringatan, teguran hingga pemecatan. Reward Dan Punishment yang ada di PT. Plato Isoiki Bandar Lampung sangat berpengaruh besar kepada loyalitas kerja karyawan. PT. Plato Isoiki sudah menerapkan sesuai dengan Syari'at Islam yaitu Dalam contoh: Islam memandang seorang buruh sebagian besar dari keluarga kita yang harus diperlakukan selayaknya dan perlu dihargai keadaannya walaupun hanya karyawan biasa, pemberian Reward yang layak bagi karyawan merupakan komponen penting 
dalam keberlangsungan usaha sebuah perusahaan. ${ }^{10}$

2. yang dilakukan pada tahun 2016 oleh Bapak Muhammad

Amin S.E "Strategi Pemasaran Multi Level Marketing Perspektif Ekonomi Islam (Studi Kasus Ada PT. Natural Nusantara Cabang Purwokerto).” Dalam skripsinya penulis membahas tentang strategi pemasaran Multi Level Marketin Perspektif Ekonomi Islam, (studi kasus PT.Natural Nusantara Cabang Purwokerto) yang praktiknya sesuai dalam hukum Islam. strategi pemasaranyang digunakan PT. Natural Nusantara Cabang Purwokerto tidak terdapat sistem money game atau permainan uang yang hanya menguntungkan

10 Ranita Dewi, "Tinjauan Hukum Ekonomi Islam Tentang Reward Dan Punishment Karyawan Studi Pada PT. Plato Isoiki Bandar Lampung" Skripsi Fakultas Ekonomi Dan Bisnis Islam, IAIN Raden Intan Lampung, 2017 anggota yang berada di atas dan dilarang oleh ekonomi Islam karena hanya memutarkan uang tanpa adanya produk yang dijual. Komitmen perniagaan (jual beli) dalam PT. Natural Nusantara Cabang Purwokerto berdasarkan asas tolong menolong dalam kebajikan dan taqwa menjadi falsafah dalam gerakan pemasaran produk (sudah mendapat ijin dari BPOM dan sertifikasi halal dari MUI). Adapun Adapun sistem komisi pada PT. Natural Nusantara dapat dikategorikan ke dalam akad ijarah, sedangkan sistem bonus dapat dimasukkan kedalam akad Ju'lah,yaitu boleh. ${ }^{11}$

Dari paparan singkat skripsi di atas, nampak bahwa penulis

\footnotetext{
${ }^{11}$ Muhammad Amin, "Strategi Pemasaran Multi Level Marketing Perspektif Ekonomi Islam" Studi Kasus Ada PT. Natural Nusantara Cabang Purwokerto, 2016.
} 
tersebut memiliki Objek kajian yang sama namun meskipun membahas sistem Reward dan strategi pemasaran produk PT. Natural Nusantara namun penulis lebih berfokus membahas tentang Bagaimana Sistem Reward Produk PT. Natural Nusantara Cab. Palu Timur ditinjau dalam Hukum Islam. ${ }^{12}$

Penulis mencoba mengangkat judul tentang sistem Reward produk PT. Natural Nusantara Cab. Palu Timur Ditinjau Dalam Hukum Islam dalam menambahkan penghasilan terhadap pegawai dan motivasi agar lebih meningkat prestasinya. sehingga relevansi penelitian antara penjual produk PT. Natural Nusantara dalam meningkatkan pendapatan pegawai sesuai tidak dengan Hukum Islam sangat jelas kedua hasil penelitian di atas. dan penulis sengaja mengakat judul ini dengan berbagi pertimbangan diantaranya penulis ingin mengamati lebih dalam terkait dengan sistem Reward produk PT. Natural Nusantara Cab. Palu Timur ditinjau dalam hukum islam belum pernah di angkat dan diteliti.

Meskipun semua hasil penelitian skripsi di atas sudah banyak yang membahas masalah sistem Reward, namun tidak menutup kemungkinan untuk melakukan penelitian masalah sistem Reward dari sudut pandang yang berbeda. Karena disini penulis akan membahas bagaimana “ Sistem Reward Produk PT. Natural Nusantara Ditinjau dalam Hukum Islam Cab. Palu Timur”.

\section{Pengertian Reward}

${ }^{12}$ Ibid, 2016. 
Usaha untuk mendapatkan pegawai yang profesional sesuai dengan tuntutan jabatan diperlukan suatu pembinaan yang berkesinambunan, yaitu suatu usaha kegiatan perencanaan, pengorganisasian, penggunaan, dan pemeliharaan pegawai agar mampu melaksanakan tugas dengan efektif dan efesien. ${ }^{13}$ Sebagai langkah nyata dalam hasil pembinaan maka dirasa perlu dengan adanya pemberian Reward atau penghargaan kepada pegawai yang telah menunjukkan prestasi kerja yang baik. ${ }^{14}$

Pemberian Reward tersebut merupakan upaya pemimpin dalam memberikan dalam balas jasa atas hasil kerja pegawai, sehingga dapat mendorong bekerja lebih giat dan berpotensi.

Pemimpin memberikan Reward pada saat hasil kerja seorang

${ }^{13}$ Jusuf Irianto. Manajemen Sumber Daya Manusia, (Surabaya : Insan Cenkedia, $2011), 67$.

${ }^{14}$ Ibid, 67. pegawai telah memenuhi atau bahkan melebihi standar yang telah ditentukan oleh organisasi yang memberikan Reward kepada pegawai karena masa kerja dan pengapdiannya dapat dijadikan teladan bagi pegawai lainnya. Berikut definisi Reward menurut beberapa ahli:

a. Mahmudi : Reward adalah imbalan dalam bentuk uang yang diberikan kepada mereka yang dapat bekerja melampaui standar yang telah ditentukan.

b. Suhrsimi Arikunto mmenjelaskan bahwa Reward merupakan sesuatu yang diberikan kepada seseorang karena sudah mendapatkan prestasi dengan yang dihendaki. ${ }^{15}$

dengan motivasi yang tinggi dan berprestasi dalam mencapai tujuan-tujuan organisasi.

${ }^{15}$ Mahmudi, Suharsimi Arikunto, Manajemen Sumber Daya Manusia , (Surabaya : Insan Cendekia, 2001). 67-68. 
Besar kecilnya Reward yang diberikan kepada yang berhak bergantung kepada banyak hal, terutama ditentukan oleh tingkat pencapaian yang diraih. Selain itu bentuk Reward ditentukan pula oleh jenis atau wujud pencapaian yang diraih serta kepada siapa Reward tersebut diberikan kepada pegawai.

$$
\text { Setiap organisasi }
$$

menggunakan berbagai Reward atau imbalan untuk menarik, mempertahankan kelangsungan perusahaan yang telah menyediakan dan memberi motivasi terhadap Mitra-Nya agar mencapai yang diinginkan nya. Misalnya dengan cara memberikan kepada Mitra-Nya berupa sertifikat maupun berbentuk uang penghargaan ahli tugas, promosi, pujian dan pengakuan juga membantu menciptakan iklim yang menghasilkan pekerja'an yang lebih banyak tantangannya dan

memuaskan sebaliknya, para pegawai menukarkannya dengan waktu, kemampuan, keahlian, dan usaha mendapatkan imbalan yang sesuai. $^{16}$

\section{Dasar Hukum Islam Reward}

Hukum Islam yang maksud dalam penegasan istilah yang termuat dalam skripsi ini menggunakan dasar hukum Al-Qur'an adalah Dalam kajian hukum yang telah ditentukan dalam Al-qur'an masalah Ekonomi/ Muamalah. Menurut Muhammad Yusuf Musa pengertian fiqh muamalah adalah peraturanperaturan Allah Swt yang harus diikuti dan ditaati dalam hidup bermasyrakat untuk menjaga kepentingan manusia. ${ }^{17}$ Namun belakangan ini pengertian muamalah.

\footnotetext{
16 Ibid, 67.

17 KH. Basyir Ahmad Azhar, asasasas hukum muamalat (hukum perdata islam), (yogyakarta : UII pres, 2000,2004).7
} 
lebih banyak dipahami sebagai aturan-aturan Allah Swt yang mengatur hubungan manusia dengan manusia dalam memperoleh dan mengembangkan harta benda. ${ }^{18}$

PT. Natural Nusantara membuka peluang pendapatan yang bisa didapatkan oleh Distributor melalui bonus Reward. Bonus Reward dapat diperoleh seorang Distributor yang telah memiliki jaringan yang besar dan aktif sehingga tanpa bekerja langsung atau melakukan pembinaan dan perekrutan dengan sendirinya distributor tersebut akan mendapatkan reward atas jerih payah dalam penjualan produk dan menyebar luas mitra PT. Natural Nusantara. ${ }^{19}$

${ }^{18}$ Ibid, 7.

${ }^{19}$ Muhammad, Abdul Qadir Ahmad, Atho, Tsubulus Salam Syarah Bulughal Maram min Jam"i Adillatul Ahkam, Juz 3,.hlm. 156.
Reward tersebut berupa poin yang didapatkan dari grup Anggota Mitra yang telah direkrut seorang Distributor adalah hasil rekrutmen dan penjualan Distributor tersebut, di mana ketika penjualan produk atau merekrut banyak mitra, maka poin yang didapatkan juga semakin banyak untuk atasannya Upline. Padahal Allah SWT telah menetapkan akad-akad yang telah ditentukan sebagaimana firmannya Allah Swt yaitu:

a). Firman Allah Swt:

QS. Al-Ma'idah [5] 1:

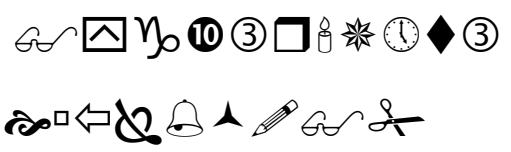

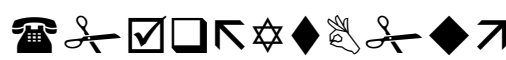

융 \& $\square \rightarrow$ ㅁ $\square \square \mathbb{E}$

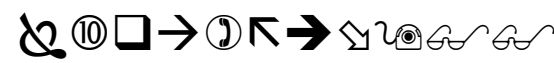

Qे

Terjemahnya: 
..."Hai orang-orang yang beriman, penuhilah aqadaqad itu'....

QS. Al-Isra [17] 34 :

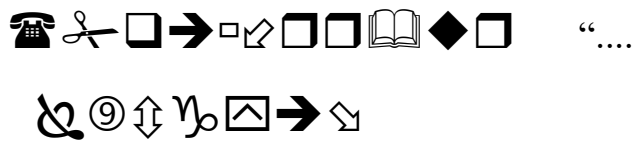

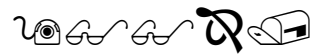

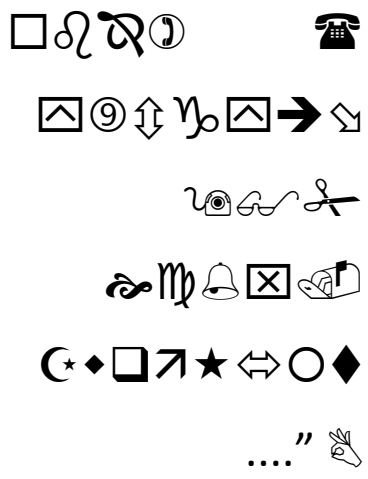

Terjemahnya :

...."Dan tunaikanlah janji-janji itu, sesungguhnya janji itu akan dimintai pertanggung jawaban"....

Berdasarkan tinjauan Hukum

Islam, Islam menganjurkan seseorang untuk memberikan janji sesuai kesepakatan. Islam menawarkan suatu penyelesaian yang sangat baik atas masalah upah dan menyelamatkan kepentingan kedua belah pihak, seperti sabda Rasulullah Saw yang diriwayatkan oleh Ibnu Majah dari Ibnu Umar bahwa Nabi Muhammad Saw bersabda.

وَعَنْ إِبْنُ عُعَرَ رَضي اللهُ عَنْهُهَ قَالَ : قَالَ

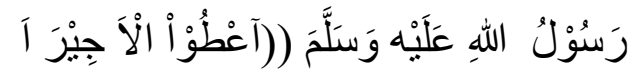

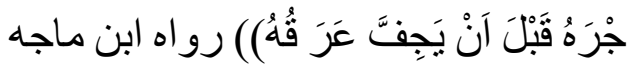

Terjemahan :

"Dari Ibnu Umar Rhadiallahu Anhuma bahwa Rasulullah SAW. Bersabda, "Berikan hak buruh sebelum kering

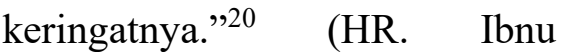
Majah/2473). Rasul memperingatkan seseorang untuk bersikap jujur dan adil dalam semua urusan mereka, dan melarang melakukan aniaya yang dapat merugikan orang lain".

MLM Syari'ah pada PT. Natural Nusantara yang berbasis syariah pada kenyataannya Reward yang sering dipraktekkan oleh seorang Upline yang sudah memiliki banyak Distributor di bawah jaringan, yang pada dasarnya adalah telah diberikan hak

${ }^{20}$ Muhammad bin Ismail Al-Amir Ash-Shan "eani, Subulus Salam Syarah Bulughul Maram, Jilid 2, (Jakarta: Darus Sunnah, 2013), hlm. 525 
sepenuhnya dari hasil penjualan Downline itu sendiri.

\section{Multi Level Marketing} Syari'ah adalah suatu konsep penyaluran barang (produk/jasa) yang memberi kesempatan kepada para konsumen untuk turut terlibat sebagai penjual dan menikmati keuntungan di dalam garis kemitraannya/sponsorisasi. Pelaksanaan Fatwa DSN MUI NO. 75/DSN/MUI. VII/2009 di PT. Natural Nusantara yogyakarta. Sistem penjualan langsung berjenjang di PT. Natural Nusantara sejauh ini sudah sesuai persyaratan preusahaan yang menjalankan Sistem Multi Level Marketing, bahkan di dalam nya ditanamkan prinsip syari'ah meskipun pada kenyataan perusahaan tersebut termaksud perusahaan umum. Sistem penjualan langsung berjenjang di PT. Natural Nusantara menggunakan sistem yang memberikan bonus kepada para Distributor berdasarkan hasil penjualan produk tanpa mengurangi jumlah keuntungan yang dimiliki downlinenya dan pelaksanaan penjualan langsung berjenjang di PT. Natural Nusantara yogyakarta sudah sesuai dengan 12 ketentuan hukum yang tercantum dalam fatwa DSN MUI NO. 75 Tahun 2009 tentang pedoman penjualan langsung berjenjang syari'ah Kata kunci Multi Level Marketing syari'ah. ${ }^{21}$

DSN MUI sudah mengeluarkan fatwa tentang MLM dengan nama Penjualan Langsung Berjenjang Syariah No 75 Tahun 2009, DSN MUI menetapkan sebagai berikut :

1). Penjualan Langsung Berjenjang adalah cara penjualan barang atau jasa melalui jaringan

${ }^{21}$ Fatwa DSN MUI NO. 75 Tahun 2009 tentang pedoman penjualan langsung berjenjang Syari'ah. Kata Kunci Multi Level Marketing Syari'ah. 
pemasaran yang dilakukan oleh perorangan atau badan usaha kepada sejumlah perorangan atau badan usaha lainnya secara berturut-turut

2). Barang adalah setiap benda berwujud, baik bergerak maupun tidak bergerak, dapat dihabiskan maupun tidak dapat dihabiskan, yang dapat dimiliki diperdagangkan, dipakai, dipergunakan, atau dimanfaatkan oleh konsumen.

3). Produk jasa adalah setiap layanan yang berbentuk pekerjaan atau pelayanan untuk dimanfaatkan oleh konsumen.

4). Perusahaan adalah badan usaha yang berbentuk badan hukum yang melakukan kegiatan usaha perdagangan barang dan atau produk jasa dengan sistem penjualan langsung yang terdaftar menurut peraturan perundangundangan yang berlaku.

5). Konsumen adalah pihak pemakai barang dan atau jasa, dan tidak untuk diperdagangkan.

6). Komisi adalah imbalan yang diberikan oleh perusahaan kepada mitra usaha atas penjualan yang besaran maupun bentuknya diperhitungkan berdasarkan prestasi kerja nyata, yang terkait langsung dengan volume atau nilai hasil penjualan barang dan atau produk jasa.

7). Bonus adalah tambahan imbalan yang diberikan oleh perusahaan kepada mitra usaha atas penjualan, karena berhasil melampaui target penjualan barang dan atau produk jasa yang ditetapkan perusahaan.

8). Ighra' adalah daya tari luar biasa yang menyebabkan orang lalai terhadap kewajibannya demi melakukan hal-hal atau transaksi 
dalam rangka mempereroleh bonus atau komisi yang dijanjikan.

9). Money Game adalah kegiatan penghimpunan dana masyarakat atau penggandaan uang dengan praktik memberikan komisi dan bonus dari hasil perekrutan/pendaftaran Mitra Usaha yang baru/bergabung kemudian dan bukan dari hasil penjualan produk, atau dari hasil penjualan produk namun produk yang dijual tersebut hanya sebagai kamuflase atau tidak mempunyai mutu/kualitas yang dapat dipertanggung jawabkan.

10). Excessive mark-up adalah batas marjin laba yang ber-lebihan yang dikaitkan dengan hal-hal lain di luar biaya.

11). Member get member adalah strategi perekrutan keanggotaan baru PLB yang dilakukan oleh anggota yang telah terdaftar sebelumnya.
12). Mitra usaha/Stockist adalah pengecer/retailer yang menjual/memasarkan produk-produk penjualan langsung.

Seseuai dalam peraturan Fatwa DSN MUI No 75 Tahun 2009 Sistem Reward produk PT. Natural Nusantara ini sudah sesuai dengan Hukum Ekonomi Islam sesuai yang disampaikan dari urutan no 1- 8 bahwa sistem Reward telah disediakan oleh perusahaan tersebut sesuai hasil kerja keras mitra usaha.

\section{Jenis-jenis Sistem Reward}

Segala sesuatu yang diberikan organisasi untuk memuaskan satu atau beberapa kebutuhan individu disebut sebagai penghargaan atau Reward. $^{22}$ Menurut Long dalam jusuf, jenis penghargaan ini

22 Jusuf Irianto, Manajemen Sumber Daya Manusia, (Surabaya : Insan Cendekia, 2001). 68 
dikelompokkan menjadi dua kategori yaitu :

\section{Penghargaan}

\section{(Extrinsic Rewards)}

Penghargaan extrinsik adalah segalag sesuatu yang akan diteriam oleh seseorang dari lingkungan tempat dia bekerja, dimana sesuatu yang akan diperolehnya tersebut sesuai dengan harapannya ${ }^{23}$. Menurut Gibson dkk, penghargaan ekstrinsik mencakup penghargaan yang bersifat finansial, promosi dan imbalan untuk memuaskan kebutuhan dasar (Basic Needs), keamanan, kebutuhan sosial dan kebutuhan untuk mendapat pengakuan. Sifat penghargaan ekstrinsik adalah Tangble atau dapat dirasakan secara fisik Bentuk penghargaan

ekstrinsik. $^{24}$

diantaranya adalah :

a. Insentif

Insentif merupakan pemberian uang di luar gaji yang diberikan oleh pemimpin organisasi sebagai bentuk pengakuan terhadap prestasi kerja dan kontribusi pegawai kepada organisasi. Pada dasarnya pemberian insentif senantiasa dihubungkan dengan balas jasa atas prestasi ekstra yang melebihi suatu standar yang telah ditetapkan serta telah disetujui bersama. Insentif memberikan penghargaan dalam bentuk pendapatan dalam bentuk pendapatan ekstra untuk usaha ekstra yang dihasilkan. Misalnya kepala mitra memberikan insentif kepada Downline nya yang ditugaskan untuk menjual setiap produk dan bisa menarik Downline baru agar lebih berkembang penjualan perusahaan.

1) Bonus

\footnotetext{
${ }^{24}$ Gibson, er al, Organisasi, perilaku dan proses, (Jakarta : Erlangga, 1997). 172
} 
Bonus adalah imbalan yang berupa sejumlah uang yang ditambahkan ke gaji pegawai yang mampu bekerja sedemikian rupa sehingga melampaui harapan pemimpin. Apabila pembayaran gaji pokok biasanya dilakukan setiap bulan, maka pembayaran bonus dilakukan secara variasi tergantunng pada perjanjian antara pengusaha dan pegawainya, misalnya bonus tahunan. Dengan demikian pembayaran bonus dapat bertindak sebagai insentif bagi para pekerja agar termotivasi untuk meningkatkan kinerjanya. Bonus tahunan biasanya diberikan apabila perusahaan mendapatkan laba atau keuntungan atau meliki nilai saldo positif di akhir tahun. Pemberian bonus sendiri didasarkan akan 3 hal. ${ }^{25}$

Pertama, berdasarkan jumlah unit produksi yang dihasilkan dalam satu kurun waktu tertentu. Artinya

\footnotetext{
25 Anwar Prabu Mangkunegara, Manajemen Sumber Daya Perushaaan, (Bandung: PT. Remaja Rosdakarya, 2013). 89
}

jika jumlah unit produksi yang hasilkan melebihi jumlah yang telah ditetapkan, karyawan akan menerima bonus atas kelebihan jumlah yang dihasilkannya. ${ }^{26}$

Kedua, apa bila terjadi penghematan waktu. Artinya jika pegawai menyelesaikan tugas dengan hasil yang memuaskan dalam waktu yang lebih singkat dari waktu yang seharusnya, pegawai tersebut menerima bonus dengan alasan menghemat waktu, lebih banyak pekerjaan yang dapat diselesaikan.

Ketiga, bonus diberikan berdasarkan perhitungan yang progresif. Artinya jika seorang karyawan makin lama makin mampu memproduksikan barang dalam jumlah yang semakin besar, makin besar pula bonus yang diterimanya untuk setiap kelebihan produk yang dihasilkan .

Dasar pemberian bonus pada penjelasan diatas ialah pemberian 
bonus dalam dunia kerja maupun bisnis. Dalam dunia kerja pemberian bonus dapat diberikan berdasarkan penghematan waktu. $^{27}$ Misalnya penghematan waktu ini dapat tercermin ketika seorang pegawai mampu menyelesaikan tugas yang diberikan kepadanya lebih cepat dari waktu yang ditentukan.

2) Penghargaan Secara Formal Dari Pimpinan

Saat ini banyak organisasi atau lembaga perusahaan yang menerapkan sistem pemberian penghargaan. Semua pegawai bahwa salah satu pegawai telah berprestasi dan pantas untuk diberik penghargaan. Penhargaan ini dapat berupa gelar, mendali atau sertifikat yang diberikan pada pegawai yang berprestasi. Pada umumnya waktu pemberian penghargaan ini adalah ketika organisasi tersebut melakukan kegiatan formal. Misalnya kepala

27 Sondang P. Siagan, Manajemen Sumber Daya Manusia, (Jakarta: Bumi Aksara, 1995)1. 69 perusahaan memberikan sertifikat penghargaan pada salah seorang pegawai karena beliau raji mengikutsertakan pegawai lainnya. ${ }^{28}$ 3) Pujian

Pujian adalah bentuk Reinforcement yang positif dan baik. Pujian yang diucapkan pada waktu yang tetap dapat dijadikan sebagai alat motivasi. Dalam hal ini kepada perusahaan memberikan pujian kepada salah seorang pegawai karena memberikan contoh positif bagi pegawai lain. ${ }^{29}$

4) Promosi jabatan

Promosi adalah apabila seorang pegawai dipindahkan dari satu pekerjaan ke pekerjaan lain yang tanggung jawabnya lebih besar dari pada tanggung jawab yang telah dibebankan sebelumnya. Pada umumnya setiap pegawai mendambakan promosi karena dipandang sebagai penghargaan atas keberhasilan seseorang dalam

${ }^{28}$ Ibid, 69.

29 Ibid, 69. 
menunjukkan prestasi kerja yang tinggi, sekaligus sebagai pengakuan atas kemampuan dan potensi yang bersangkutan untuk menduduki posisi yang lebih tinggi dalam organisasi. $^{30}$

Organisasi pada umumnya menggunakan 2 kriteria utama dalam mengembangkan seseorang yang dipromosikan, yaitu prestasi kerja dan senioritas. Promosi yang didasarkan pada prestasi kerja menggunakan hasil penilaian atas hasil karya yang sangat baik dalam promosi atau jabatan. Sekarang dengan demikian promosi tersebut dikatakan sebagai penhargaan organisasi atas kerja angggotannya itu.

Sedangkan praktek promosi yang didasarkan pada senioritas berarti pegawai yang paling berhak dipromosikan adalah yang masa kerjanya paling lama. Namun pada

30 Jusuf Irianto, Manajemen Sumber Daya Manusia, (Surabaya: Insan Cendeki, 2001), 67. umumnya pada lembaga perusahaan kepala perusahaan memberikan promosi pada kareir yang disediakan kepada seorang pegawai karena perjuangannya memperlebar erderan produk perusahaan .

b. Penghargaan Intrinsik (Intrinsic Reward)

Penghargaan intrinsik adalah sesuatu yang dirasakan langsung oleh seseorang ketika dirinya melakukan sesuatu. Sesuatu yang dirasakan ini dapat berupa kepuasan dalam melakukan sesuatu, perasaan lega karena telah menuntaskan sesuatu serta adanya peningkatan kepercayaan diri dan sebagainya.

Bentuk penghargaan ini mengacu pada faktor-faktor pekerjaan itu sendiri atau job context seperti pekerjaan memberi tantangan dan menarik, puas atas memberi umpan balik, dan atributatribut pekerjaan menantang lainnya. Sumber penghargaan intrinsik ini berasal dari individu itu sendiri. 
Menurut gibson Dkk. Imbalan intrinsik mancakup rasa penyelesaian dalam pencapaian prestasi otonomi dan pertumbuhan pribadi. ${ }^{31}$

a. Pencapaian Prestasi

Pencapaian prestasi adalah imbalan yabg ditata tersendiri yang diperoleh jika seseorang mencapaian suatu tujuan yang menantang Mc.Cleland dalam mencapai prestasi. Gibson menemukan adanya perbedaan individual dalam perjuangan untuk prestasi. $^{32}$ Beberapa individu mencari tujuan yang menantang sementara lainnya mencari tujuan yang rendah.

Jadi dapat diketahui bahwa tujuan yang menantang atau sukar akan menghasilkan tingkat prestasi individual yang lebih tinggi dibanding tujuan yang sedang atau rendah. Akan tetapi perbedaan individu merupakan hal yang perlu dipertimbangkan sebelum dicapai

31 Gibson et, al. Organisasi, perilaku, struktur dan proses, (jakarta: erlangga , 1997), 176-177.

${ }^{32}$ Ibid, 176-177. kesimpulan tentang pentingnya imbalan prestasi. Dalam hal ini pencapaian prestasi dapat menjadi sebuah imbalan intrinsik apabila, seorang pegawai dapat mencapai suatu prestasi dan mendapat kepuasan kerja didalam pegawai tersebut.

b. Otonomi

Banyak orang menginginkan pekerjaan yang memberikan mereka hak istimewa untuk membuat keputusan dan bekerja tanpa diawasi secara ketat, Rasa otonomi dapat berasal dari kebebasan melakukan apa yang terbaik menurut karyawan yang bersangkutan dalam situasi yang khusus. Dalam menciptakan tugas yang menimbulkan rasa otonomi.

c. Pertumbuhan pribadi

Pertumbuhan pribadi setiap individu adalah suatu pengalaman yang unik. Seseorang yang sedang mengalami pertumbuhan merasakan perkembangan.

Dengan 
pengembangan

kesanggupan,

seseorang mampu memaksimalkan

atau paling tidak memuaskan potensi

keahliannya, sebagian orang sering

kecewa terhadap tugas dan organisasi

mereka jik mereka tidak diizinkan

atau didorong mengembangkan

keahlian mereka. ${ }^{33}$ Dalam hal ini

kepala perusahaan hatus memberikan

pelatihan atau seminar untuk

mengembangkan potensi pegawai

sebagai pegawainya. Sehingga

nantinya pertumbuhan pribadi setiap

pegawai dapat tercapai keingin nya.

\section{Tujuan Reward}

Adapun tujuan pemberian reward yang utama adalah:

\section{Menarik (Attract)}

Reward harus mampu menarik orang yang berkualitas untuk menjadi anggota organisasi.

2. Mempertahankan (Retain)

Reward juga bertujuan untuk mempertahankan pegawai dari incaran organisasi lain. Sistem reward yang baik dan menarik mampu meminimalkan jumlah pegawai yang keluar.

3. Memotivasi (Motivate)

Sistem reward yang baik harus mampu meningkatkan motivasi pegawai untuk mencapai prestasi yang tinggi.

\section{Sistem Pemberian Reward}

Dalam usaha untuk memenuhi tujuan-tujuan reward tersebut, perlu diikuti tahapan-tahapan dalam pemberian reward yaitu:

1. Melakukan analisis pekerjaan, artinya perlu disusun sistem jabatan, uraian pekerjaan dan standar pekerjaan yang ditetapkan dalam suatu organisasi

2. Melakukan penilaian pekerjaan, dalam melakukan penilaian pekerjaan diusahakan terusunnya urutan peringkat pekerjaan, penentuan nilai untuk setiap pekerjaan, susunan perbandingan dengan pekerjaan lain dalam organisasi

\footnotetext{
${ }^{33}$ Ibid, 177-178.
} 
3. Melakukan survei berbagai sistem penghargaan yang berlakukan untuk menentukan keadilan eksternal yang didasarkan pada sistem penghargaan ditempat lain.

4. Menentukan harga setiap pekerjaan untuk menentukan penghargaan yang akan diberikan. Dalam mengambil langkah ini dilakukan perbandingan antara nilai berbagai pekerjaan dalam organisasi dengan nilai yang berlaku di tempat lain pada umumnya. ${ }^{34}$

\section{HASIL PENELITIAN}

Dengan adanya pendapat para ahli diatas maka penulis menarik kesimpulan bahwa Reward merupakan sebuah bentuk pengakuan kepada suatu prestasi tertentu yang diberikan dalam bentuk material dan non material yang diberikan oleh pihak organisasi, individu atau

\footnotetext{
34 Rachmat Syafe' I, Fiqih Muamalah, (Bandung : Sinar Baru Algensido, 1994), 304.
}

pegawai agar mereka dapat bekerja dengan motivasi yang tinggi dan berprestasi dalam mencapai tujuantujuan organisasi.

Dalam wawancara yang di lakukan oleh penulis dengan Ibu Nita Febrianti mengenai Reward yaitu :

Reward adalah bonus yang telah diberikan kepada karyawan perusahaan, yang berprestasi dalam mempromosikan setiap produk yang disediakan oleh perusahaan agar karyawan tersebut lebih semangat dalam bekerja dan mampu membantu perusahaan lebih berkembang. Bisnis PT. Natural Nusantara ini siapa yang bekerja keras maka ia yang akan rasakan hasilnya. Seperti saya dengan Ibu Lieda. Ibu Liesda ini downline saya, kalau saya upline nya. Tetapi beliau yang lebih berjuang dalam menjalankan bisnis ini sehingga dia lebih tinggi peringkatnya dari pada saya. $^{35}$

Pendapat yang sama juga dikatakan oleh bapak Didi Wahjudi mengenai Reward yaitu:

Reward merupakan suatu penghargaan/bonu yang disediakan oleh perusahaan untuk karyawan, agar karyawan nya tetap rajin bekerja dan berprestasi dalam

\footnotetext{
35 Ibu Nita Febrianti, Hasil Wawancara Mitra PT. Natural Nusantara,di Jl. Tombolotutu Kec. Mantikulore, Kota Palu 19 Agustus 2019
} 
mempertahankan kelangsungan perusahaan tersebut. Sistem Reward produk PT. Natural Nusantara ini sudah sesuai perjanjian pihak perusahaan terhadap semua mitra PT. Natural Nusantara akan memberikan reward apa bila dalam bekerja begitu baik dan bisa mengembangkan perusahaan tersebut. ${ }^{36}$

Penulis dapat menyipulkan bahwa Reward merupakan sebuah penghargaan atau bonus yang disediakan oleh pihak perusahaan, untuk mitra PT. Natural Nusantara agar mereka dapat bekerja dengan motivasi yang tinggi dan berprestasi dalam mencapai tujuan-tujuan yang mereka iming-imingkan. Selain itu mitra tersebut bisa mengembangkan dan melebarluaskan peminat produk PT. Natural Nusantara.

Pada Prinsipnya secara umum mitra PT. Natural Nusantara baik keuntungan yang mereka dapatkan

\footnotetext{
${ }^{36}$ Pak Didi Wahjudi, Hasil Wawancara Mitra PT. Natural Nusantara,di J1. Tombolotutu Kec. Mantikulore, Kota Palu 19 Agustus 2019
}

lebih tinggi dari pada Reward yang mereka di berikan sehingga mereka lebih tinggi kemauan bertahan dibisnis PT. Natural Nusantara. Reward suatu penambahan pendapatan bagi mitra PT. Natural Nusantara setiap bulan nya. Karena prinsip Mitra PT. Natural Nusantara adalah mencari keuntungan dan penambahan yang begitu menjaminkan untuk kesuksesan bagi mitra PT. Natural Nusantara. Meskupun reward yang diberikan itu kecil bagi mitra PT. Natural Nusantara yang baru gabung jadi mitra PT. Natural Nusantara.

Pada wawancara yang dilakukan penulis terhadap salah satu Mitra PT. Natural Nusantara Bapak Andi :

Ada juga mitra PT. Narural Nusantara yang bangkrut karena kurang aktif dalam mempromosikan ke konsumen/pembeli. Apalagi dalam dunia maya kurang penjualan karena sudah banyak mitra PT. Natural Nusantara yang sering 
menjatuhkan harga yang lebih murah sehingga mitra mitra lainnya kurang penjualan karena itu satu syarat mendapatkan Reward. Dari hasil pengumpulan poin di setiap penjualan produk. $^{37}$

Dari sudut pandang hukum ekonomi setiap usaha memiliki tujuan yang sama yaitu memaksimalkan keuntungan. Namun, bagi pengusaha atau penjual seorang muslim, hal yang penting adalah memaksimalkan keuntungan dari dua sisi yaitu untuk tujuan dunia dan akhirat. Keuntungan dunia dan ukhwari dapat diperoleh dengan efesiensi penggunaan faktor produksi dan Reward. Hal inilah yang menjadi obyek penelitian penulis pada Sistem Reward Produk PT. Natural Nusantara Cab. Palu Timur.

Sebelum lanjut pada Sistem Reward produk PT. Natural Nusantara, sebaiknya perlu

${ }^{37}$ Bapak Andi, Mitra Tertinggi, PT. Natural Nusantara Cab. Palu Timur, Hasil Wawancara 19 Agustus 2019 disampaikan latar belakang Mitra

PT. Natural Nusantara memilih gabung di bisnis ini. Hasil penelitian menunjukan bahwa mitra PT. Natural Nusantara memilih bisnis PT. Natural Nusantara dengan berbagai alasan, diantaranya yang di kemukakan oleh Ibu Liesda berikut:

Alasan saya bergabung Dibisnis PT. Natural Nusantara Cab. Palu Timur ini adalah ingin punya penghasilan sendiri, tidak mau terikat dengan orang lain dan pingin orang yang sukses dan bisa biayayi anakanak saya, agar merasakan sekolah yang mahal dan kemewahan. Alhamdulillah dengan gabung dibisnis PT. Natural Nusantara ini bisa tercapai semua bahkan lebih dari itu. ${ }^{38}$

Alasan lain dikemukakan oleh Ibu Putri Amelia, sebagai berikut:

Alasan saya bergabung dibisnis PT. Natural Nusantara Cab. Palu Timur ini karena ingin suami saya berhenti dari kerjanya dan saya tidak mau terikat dengan pekerjaan saya, saya ingin bebas dan mempunyai penghasilan yang memnuhi

${ }^{38} \mathrm{Ibu}$ Liesda, Mitra Tertinggi, PT. Natural Nusantara Cab. Palu Timur, Hasil Wawancara 19 Agustus 2019 
kebutuhan dan impian pengen punya rumah yang memah. ${ }^{39}$

Pendapat selajutnya di kemukakan pada Ibu Nur Yana Nuhun ini

Alasan saya gabung dibisnis PT. Natural Nusantara Cab. Palu Timur ini adalah karena ingin punya penghasilan tambahn sendiri tampan dari penhasilan suami karena suami saya tidak perna memberi saya nafkah sehingga saya mencari penhasilan sendiri. ${ }^{40}$

Berdasarkan keterangan di atas, tampak bahwa Mitra PT. Natural Nusantara Cab. Palu Timur memilki alasan yang sama yaitu untuk memiliki penghasilan sendiri dan memenuhi kebutuhan keluarga, baik kebutuhan pribadi, maupun kebutuhan anak-anak.

Adapun sistem Reward produk PT. Natural Nusantara oleh mitra yang di sediakan oleh perusahan itu sendiri sesuai penjualan setiap mitra Natural Nusantara.

39 Ibu Putri Ameliya Mitra PT. Natural Nusantara Cab. Palu Timur Hasil Wawancara 19 Agustus 2019

${ }^{40} \mathrm{Ibu}$ Nuryana Nuhun, Mitra PT. Natural Nusantara Cab. Palu Timur, Hasil Wawancara 19 Agustus 2019
Reward di kirimkan langsung kerekening mitra masing-masing, reward di sediakan sesuai dengan peringkat yaitu: distributor 50-100, manager 200-400, silver manager 1 juta- 1 juta 600, gold manager 2 juta -2 juta 500, pearl manager 3 juta -5 juta, emerald manager 7 juta -12 juta, diamond directur 12 juta -30 juta,executiv diamond directur 30 juta - 50 juta, double diamond directur 5- juta -100 juta, dan crown diamond directur 100 juta -150 juta.

Dalam sistem Reward PT. Natural Nusantara Cab. Palu Timur para mitra banyak memiliki kendala yang paling besar yaitu ssetiap anggota kurang fokus menjalakan nya sehingga kadang kurang mendapatkan Reward. Dan upline tidak merasakan di rugikan karena masi banyak mitra lain yang lebih serius menjalakan bisnis ini karena 
apa bila anggota nya lebih 10 maka

yang aktif tiga atau lima orang maka

dia tetap untung karena masi ada

yang aktif menjalankan dan selalu

closing.

Sistem Reward Seperti ini

penulis dapatkan dari hasil

wawancara mitra PT. Natural

Nusantara yang mendapat reward

seabagaimana yang dikemukakan

beberapa Mitra PT. Natural

Nusantara yaitu :

Ibu Liesda : saya mendapat reward pertama gabung bisnis PT.Natural Nusantara 200 ribu, setelah saya jalankan selama 2 tahun. alhamdulillah say menerima reward tiket jalan-jalan, dan umbroh, kalau tahun ini reward yang saya terimah itu dalam bentuk uang sebanyak 30 juta perbulanan itu semua bantuan dari anggota saya. ${ }^{41}$

Ibu Putri Ameliya : saya mulai gabung di bisnis PT. Natural Nusantara pada tahun 2017, awalnya gabung di bisnis PT. Natural Nusanatar. itu hanya sebagai pemakai setelah beberapa bulan ada yang nanya, ke saya pakai produk

41 Ibu Liesda, Mitra Tertinggi, PT. Natural Nusantara Cab. Palu Timur, Hasil Wawancara 19 Agustus 2019 apa setelah saya kasih tau malah order dengan saya di situ lah mulai saya jalankan bisnis karena melihat keuntungannya yang begitu besar selain itu saya mendapatkan Reward dalam bentuk uang pertama baru 200 ribu lama-lama jadi 2 juta lebih. ${ }^{42}$

Ibu Nuryana Nuhun : saya baru gabung dibisnis PT. Natural Nusantara, baru 6 bulan saya sudah menikmati keuntungannya yang saya dapatkan. tetapi Reward yang saya dapatkan hanya sedikit perbulan nya sekitar 60 ribu sampai 100 ribu setiap bulan nya padahal saya selalu closing, kekurangan saya disini karena tidak bisa menarik member baru, Saya kurang kerja keras dalam memasarkan produk dan melebar luaskan aggota mitra baru, Dan menurut saya sudah sesuai dengan hukum Islam. ${ }^{43}$

Ibu Hasma : saya baru gabung baru dua bulan saya sudah bisa mengumpulkan poin sampe 1000 poin. tetapi Reward yang saya dapatkan pada bulan juni baru sedikit masi 300 ribu saja padahal poin yang saya kumpulkan 1000 poin saya tidak merasa dirugikan disini karena saya dapat bonus perbulan 300rb padahal saya baru masuk saya sudah bisa mengumpulkan poin sampe

42 Ibu Putri Ameliya, Mitra Tertinggi, PT. Natural Nusantara Cab. Palu Timur, Hasil Wawancara 19 Agustus 2019

43 Ibu Nuryana Nuhun, Mitra Tertinggi, PT. Natural Nusantara Cab. Palu Timur, Hasil Wawancara 19 Agustus 2019 
1000 pv tepapi saya kurang menarik anggota baru. ${ }^{44}$

Ibu Sutarti : saya gabung di Bisnis Natural Nusantara, ini saya sangat puas dalam keuntungan nya. Keuntungan saya dapatkan perbulan nya 1 juta, kalau masalah Reward saya baru mendapatkan 300 ribu saja tapi saya sudah bersyukur mendapat penghasilan yang begitu besar. ${ }^{45}$

Ibu Wati : saya mulai gabung di bisnis Natural Nusantara pada tahun 2016 bulan september, Downline dibawahku sudah 10 orang tetapi mereka tidak aktif semua sehingga saya tidak naik peringkat sampe ke silver manager hanya tetap di peringkat manager tetapi saya sudah mendapatkan reward 300-1juta alhamdulillah gabung di PT. Natural Nusantara ini bisa mengubah pendapat saya. Menurut saya sudah sesuai dengan Hukum Islam sistem Reward. ${ }^{46}$

Ibu Umi Kalsum saya bergabung di PT. Natural Nusantara dari tahun 2017, saya awalnya bergabung hanya

44 Ibu Hasma, Mitra Tertinggi, PT. Natural Nusantara Cab. Palu Timur, Hasil Wawancara 19 Agustus 2019

45 Ibu Sutarti, Mitra Tertinggi, PT. Natural Nusantara Cab. Palu Timur, Hasil Wawancara 19 Agustus 2019

46 Ibu Wati, Mitra Tertinggi, PT. Natural Nusantara Cab. Palu Timur, Hasil Wawancara 28 Agustus 2019 sebagai pemakai. Setelah lama bergabung di PT. Natural Nusantara saya mencoba menjalakan bisnis ini semakin hari berjalan bisnis semakin banyak keuntungan yang saya dapatkan selain itu saya mendapatkan reward perbulan-nya sebesar 1 juta. Menurut saya sistem reward sudah sesuai dengan Hukum Islam karena saya sudah merasakan reward yang diberikan oleh perusahaan. $^{47}$

Ibu Fanhi saya mulai bergabung dari PT. Natural Nusantara dari Tahun 2018, saya bergabung karena melihat teman saya pendapatan nya begitu besar selama ia bergabung di PT. Natural Nusantara. Dari situ lah saya bergabung di PT. Natural Nusantara untuk menjalankan bisnis ini dan saya sudah mendapatkan keuntungan yang begitu besar selain itu saya mendapat kan reward perbulan nya yang disediakan perusahaan. ${ }^{48}$

Ibu Mahda saya sangat senang gabung di PT. Natural Nusantara ini karena saya sudah mendapatka reward sesuai poin yang saya kumpulkan dalam penjual produk selain itu saya mendapatkan keuntungan dari penjualan dan produk PT. Natural Nusantara ini banyak yang minati sehingga saya

${ }^{47}$ Ibu Umi Kalsum, Mitra Tertinggi, PT. Natural Nusantara Cab. Palu Timur, Hasil Wawancara 19 Agustus 2019

48 Ibu Fanhi, Mitra Tertinggi, PT. Natural Nusantara Cab. Palu Timur, Hasil Wawancara 28 Agustus 2019 
sangat senang gabung di PT. Natural Nusantara. ${ }^{49}$

Ibu Nita Febrianti saya bergabung di PT. Natural Nusantara sudah 5 tahun saya menjalakan bisnis ini dan saya sangat puas dengan pemberian bonus yang telah sediakan perusahaan dalam perbulan selain itu saya mendapatkan keuntungan yang begitu besar. $^{50}$

Ibu Fitri : saya mulai gabung di bisnis PT. Natural Nusantara pada tahun 2017, awalnya gabung di bisnis PT. Natural Nusanatar. itu hanya sebagai pemakai setelah beberapa bulan ada yang nanya, ke saya pakai produk apa setelah saya kasih tau malah order dengan saya di situ lah mulai saya jalankan bisnis karena melihat keuntungannya yang begitu besar selain itu saya mendapatkan Reward dalam bentuk uang pertama baru 200 ribu lamalama jadi 2 juta lebih. ${ }^{51}$

Ibu Rosdiana : saya baru gabung dibisnis PT. Natural Nusantara, baru 8 bulan saya sudah menikmati keuntungannya yang saya dapatkan. tetapi Reward yang saya dapatkan hanya sedikit perbulan nya sekitar 60 ribu sampai 200 ribu setiap bulan nya

49 Ibu Mahda, Mitra Tertinggi, PT. Natural Nusantara Cab. Palu Timur, Hasil Wawancara 28 Agustus 2019

50 Ibu Nita Febrianti, Mitra Tertinggi, PT. Natural Nusantara Cab. Palu Timur, Hasil Wawancara 19 Agustus 2019

51 Ibu Fitri, Mitra Tertinggi, PT. Natural Nusantara Cab. Palu Timur, Hasil Wawancara 19 Agustus 2019 padahal saya selalu closing, kekurangan saya disini karena tidak bisa menarik member baru, Saya kurang kerja keras dalam memasarkan produk dan melebar luaskan aggota mitra baru, Dan menurut saya sudah sesuai dengan hukum Islam. ${ }^{52}$

Sistem Reward Seperti ini penulis

dapatkan dari hasil wawancara mitra PT. Natural Nusantara yang tidak serius menjalankan bisnis ini seabagaimana yang dikemukakan beberapa Mitra PT. Natural Nusantara yang tidak serius menjalankan yaitu :

Ibu Andi Ratna, saya bergabung dari tahun 2019, saya bergabung hanya ingin mendapatkan harga murah dan sebagai pemakai tidak menjalankan bisnis ini PT. Natural Nusantara ini. Karena saya tau manfaat produk nya yang begitu bagus. ${ }^{53}$

52 Ibu Rosdiana, Mitra Tertinggi, PT. Natural Nusantara Cab. Palu Timur, Hasil Wawancara 19 Agustus 2019

53 Ibu Andi Ratna, Mitra Tertinggi, PT. Natural Nusantara Cab. Palu Timur, Hasil Wawancara 19 Agustus 2019 
Ibu Melfin, saya bergabung pada tahun 2018, saya bergabung hanya ingin menjalankan bisnis PT. Natural Nusantara tetapi saya kurang aktif dalam mempromosikan produk PT. Natural Nusantara sedangkan dalam menjalankan bisnis ini harus punya mutu dan kemauan. ${ }^{54}$

Sri Wahyuni saya bergabung di PT. Natural Nusantara dari tahun 2019, saya bergabung karena ingin mendapatkan harga murah dari produk PT. Natural Nusantara ini agar saya dapat membeli semua produk-nya. ${ }^{55}$

Ibu Ervina, saya bergabung dari tahun 2019, saya bergabung hanya ingin mendapatkan harga murah dan sebagai pemakai tidak menjalankan bisnis ini PT. Natural Nusantara ini. Karena saya tau manfaat produk nya yang begitu bagus. ${ }^{56}$

Ibu Anisa Fitri, saya bergabung pada tahun 2018, saya bergabung hanya ingin menjalankan bisnis PT. Natural Nusantara tetapi saya

${ }^{54}$ Ibu Melfin, Mitra Tertinggi, PT. Natural Nusantara Cab. Palu Timur, Hasil Wawancara 19 Agustus 2019

${ }^{55}$ Ibu Sri Wahyuni, Mitra Tertinggi, PT. Natural Nusantara Cab. Palu Timur, Hasil Wawancara 19 Agustus 2019

56 Ibu Andi Ratna, Mitra Tertinggi, PT. Natural Nusantara Cab. Palu Timur, Hasil Wawancara 19 Agustus 2019 kurang aktif dalam mempromosikan produk PT. Natural Nusantara sedangkan dalam menjalankan bisnis ini harus punya mutu dan kemauan. ${ }^{57}$

Penulis mewawancarai 30 mitra PT. Natural Nusantara di Kota Palu, dari hasil wawancara tersebut ada 26 mitra PT. Natural Nusantara yang tidak dirugikan karena Reward yang mereka terimah sudah sesuai yang mitra harapkan dan ada juga 4 orang mitra yang tidak serius menjalankan bisnis PT. Natural Nusantara . Oleh karena itu penulis menyipulkan bahwa sistem Reward yang diberikan oleh perusahaan sudah sesuai dengan hukum Islam karena yang dibawahnya tidak dirugikan dan tetapi kalau dilihat disisih baik nya disini dari kerja kerasnya mitra PT. Natural Nusantara agar bisa mendapatkan Reward tersebut.

57 Ibu Anisa Fitri, Mitra Tertinggi, PT. Natural Nusantara Cab. Palu Timur, Hasil Wawancara 19 Agustus 2019 
Kebanyakan Upline memberikan

\section{PENUTUP}

\section{Kesimpulan}

Berdasarkan hasil penelitian dan pembahasan pada bab sebelumnya, maka dapat ditarik kesimpulan, sebagai berikut:

1. Sistem Reward produk PT. Natural Nusantara Cab. Palu Timur ini suda sesuai dengan hukum Islam terbagi kepada Dua Sistem :

a. Para mitra PT. Natural Nusantara Cab. Palu Timur. Sistem Reward sudah sesuai dengan hukum islam. Mitra PT. Natural Nusantara bekerja keras dalam penjualan dan mencari mitra baru yang lebih luas.

Dan perusahaan telah menyediakan sesuai kerja keras seorang mitra PT. Natural Nusantara

b. Para Mitra PT. Natural Nusantara Cab. Palu timur poin sesuai penjualan Downline. Setiap Upline memberikan semangat dan mengajarkan Downline nya agar lebih meninggkat penjualan nya selain itu seorang Upline memberikan saran agar Downline bisa menyetok produk sendiri dan diberikan dengan harga dibawah harga anggota sehinga Downline nya mendapatkan keuntungan yang lebih tinggi.

2. Sistem Reward produk PT. Natural Nusantara Cab. Palu Timur Ditinjau Dalam Hukum Islam ialah sistem reward dalam bidang bisnis MLM apa bila sesuai dengan hukum islam tidak merugikan orang lain sudah dikemukakan dalam bab 2 syarat dan rukun sistem Reward. Namun, pada sistem Reward produk PT. Natural Nusantara sudah sesuai dengan hukum islam karena sistem 
Reward telah di sediakan Reward sehingga perusahaan tidak terhadap Dowline agar merekan menjajikan saja disini ada lebih semangat dan tidak merasa di produknya yang langsung di jual. rugikan.

dengan kerja keras untuk mencari anggota agar bisa mencapai Reward yang akan disediakan perusahaan..

\section{Saran}

1. Hendaknya PT. Natural Nusantara sistem Reward, seorang
Upline lebih memberikan motivasi 2. Hendak mitra PT. Natural Nusantara Cab. Palu Timur harus memberikan saran, ajaran yang bermanfaat bagi mereka agar lebih sukses kedepan nya. Dan bisa seperti Mitra PT. Natural Nusantara lain. 



\section{E. DAFTAR PUSTAKA}

Aedy Hasan, Teori Dan Aplikasi

Ekonomi

Pembangunan

Prespektif

Islam,

Yogyakarta :Graha Ilmu, 2011.

https://Universitas Sumatera Utara.

Kampus/uins/Sistem Penghargaan

diakses 18 februari 2019.id.com

Edwin Mustafa, Nasution, Budi

Setyanto, Nurul Huda,

Muhammad Arief Mufraeni, Bey

Safta Utama Pengenalan Ekslusif

Ekonomi Islam Jakarta: Prenda

Media Group, 2007.

Mustafa Edwin Nasution, Budi Setyanto, Nurul Huda, Muhammad Arief Mufraeni, Bey Safta Utama Pengenalan Ekslusif Ekonomi Islam ( Jakarta: Prenda Media Group, 2007), Hlm. 15.

Irianto Jusuf, Manajemen Sumber Daya Manusia, (Surabaya : Insan Cendekia, 2001), H.67

Ibid, h.67

Muhammad „Abdul Qadir Ahmad „Atho, Tsubulus Salam Syarah Bulughal Maram min Jam" $i$ Adillatul Ahkam, Juz 3,.hlm. 156.

Anwar Prabu Mangkunegara, Manajemen Sumber Daya Perushaaan, (Bandung: PT.Remaja Rosdakarya, 2013), hal. 89

Sondang P. Siagan, Manajemen Sumber Daya Manusia, (Jakarta: Bumi Aksara, 1995), Hl. 69
Ibid, hl. 69

Irianto Jusuf, Manajemen Sumber Daya Manusia, (Surabaya: Insan Cendeki, 2001), hal. 67

et, al Gibson. Organisasi, perilaku, struktur dan proses, (jakarta: erlangga , 1997), hal. 176-177

Syafe' I Rachmat, Fiqih Muamalah, (Bandung : Sinar Baru Algensido, 1994), Hal. 304

Suryabrata Sumadi, Metodologi Penelitian, (Cet.23 Jakarta : PT RajaGrafindo, 2013) h.75

Sutrisno Hadi, Metodologi Resears, (Yokyakarta: Fakultas Psikologi UGM, t,th), h.42

Hadi Amirul dan Haryono, Metodologi Penelitian Pendidikan, cet. I; (CV. Pustaka Setia, 1998) h.110

Moleong Lexy J, Metodologi Penelitian Kualitatif, Cet. X; (Bandung:Remaja Rosda Karya, 2000) h.103

Suprayogo Imam, Metodologi Penelitian Sosial-Agama, (Banding: PT. Remaja Rosdakarya,2000) h.194

Suharsimi, Manajemen Sumber Daya Manusia, (Surabaya : Insan Cendekia, 2001), H.67

Muhammad bin Ismail Al-Amir Ash-Shaneani, Subulus Salam Syarah Bulughul Maram, Jilid 2, (Jakarta: Darus Sunnah, 2013), hlm. 525 